\title{
Reprezentacje władzy w grach komputerowych. Porównanie Wiedźmina III oraz Dragon Age: Inqusition
}

Bartłomiej Schweiger 


\section{Interpretacje}

\section{Reprezentacje władzy w grach komputerowych. Porównanie Wiedźmina III oraz Dragon Age: Inqusition}

Bartłomiej Schweiger

TEKSTY DRUGIE 2017, NR 3, S. 276-293

DOI: $10.18318 /$ td.2017.3.17

G łównym tematem niniejszego tekstu jest analiza tego, w jaki sposób w grach Wiedźmin III: Dziki gon ${ }^{1}$ i Dragon Age: Inkwizycja ${ }^{2}$ są przedstawione reprezentacje politycznej władzy. Na wstępie trzeba zaznaczyć, że artykuł ten jest sprawozdaniem z pierwszej fazy badań prowadzonych przez autora w ramach jego pracy nad doktoratem. Jest więc częścią większego projektu, który zakłada, że do pełnego zrozumienia funkcjonowania reprezentacji władzy w danym dziele konieczne jest zbadanie nie tylko jego samego, ale też tego, w jaki sposób funkcjonuje ono wśród odbiorców, w jaki sposób powstawało i jak interpretują je jego twórcy. Przedstawiona tu część stanowi podstawę dalszych badań nad problematyką reprezentacji władzy w grach komputerowych, o bardziej socjologicznym charakterze. Dlatego też nie

\section{Bartłomiej \\ Schweiger - \\ socjolog, groznawca, doktorant IS UJ, Pra- \\ cuje nad doktoratem porównującym sposoby reprezentacji władzy w Wiedźmi- nie III i Dragon Ager: Inquisition. Publiko- wał m. in w ${ }_{m ! \prime}$ Kul- turze Popularnej", "Czasie kultury" oraz czasopiśmie "Ha!Art".}

1 WB Games (Firm), and Warner Bros. Interactive Entertainment. The Witcher III: Wild Hunt, 2015.

2 BioWare Corp, Electronic Arts (Firm), and Mythic Entertainment (Firm). Dragon Age: Inquisition, 2014. 
stawia jednoznacznych odpowiedzi na temat statusu reprezentacji władzy w wyżej wymienionych tytułach, a jedynie wstępne ustalenia konieczne dla dalszych etapów analizy. Metody zastosowane w tej części badania mają charakter analizy treści i są konieczne do skonstruowania narzędzi, którymi badani będą odbiorcy i wytwórcy interesujących dla badania tytułów.

Wiedźmin: Dziki Gon i Dragon Age III: Inkwizycja zostały wybrane ze względu na łączące je podobieństwa. Obydwie serie są dużymi mainstreamowymi produkcjami, które odniosły finansowy i krytyczny sukces oraz mają duże grono oddanych fanów. Projekt skupia się na tego typu grach z kilku powodów. Po pierwsze, wielu badaczy, jak np. Fiske, twierdzi, że właśnie sukces dzieła jest dowodem jego kulturowej doniosłości i powinien stanowić przyczynek do ich lepszego zbadania. Po drugie, sukces ów jest wskaźnikiem zasięgu kulturowego oddziaływania dzieł. Po trzecie, duże produkcje tego typu znajdują się obecnie w kognitywistycznie rozumianym jądrze prototypu gry wideo ${ }^{4}$. Należą więc do zbioru kulturowych artefaktów, będącego grupą odniesienia, w stosunku do której definiuje się to, co możemy uznać za grę komputerową, a co nie. Dodatkowo w obydwu grach położono nacisk zarówno na ich fabułę, jak i na rozbudowany system zasad, znajdują się więc na środku spektrum, rozciągającego się między visual novels, skupionymi wyłącznie na narracji i wyposażonymi w jedynie rudymentarny zbiór zasad, a grami takimi jak Tetris, zupełnie narracji pozbawionymi i opierającymi się wyłącznie na zasadach. W warstwie narracyjnej obydwa wybrane tytuły odwołują się do tradycji literatury fantastycznej. Różni je to, że jedna powstała w kanadyjskim studio, będącym częścią centralnego subpola produkcji gier komputerowych, a druga w polskim, będącym częścią semiperyferyjnego polskiego pola produkcji gier komputerowych. Ze względu na tę różnicę, nadają się one bardzo dobrze do porównania w interesujących dla badania kwestiach.

Autor zdaje sobie sprawę z ograniczeń metody, jaką jest studium przypadku, oraz z tego, że takie badanie siłą rzeczy bardziej nadaje się do dogłębnego porównania dwóch tytułów niż do przedstawiania szerszego kontekstu pola wytwórstwa kulturowego, w którym funkcjonują. Jednakże szerszy kontekst funkcjonowania polskiego i zachodniego pola wytwórstwa gier wideo autor opisał już w swoim poprzednim badaniu będącym analizą porównawczą

J. Fiske Television culture, Methuen, London 1987.

4 E. Rosch, B.B. Lloyd \& Social Science Research Council (U.S.). Cognition and categorization, N.J:

L. Erlbaum Associates, Hillsdale 1978. 
wielu gier centralnych i półperyferyjnych ${ }^{5}$. Problemem poprzedniej pracy był brak możliwości dogłębnego przeanalizowania elementów zawartych w grach będących jej przedmiotem. Stąd też obecne badanie, i jego cel: dużo dokładniejsza analiza mniejszej liczby tytułów, której wynikiem mają być kategorie, pozwalające na stworzenie bardziej pogłębionego badania przekrojowego.

Główną metodą wykorzystaną w opisanej w artykule części badania była wspomagana komputerowo analiza zawartości intr, outr, cutscen, oraz sekwencji dialogowych obecnych w obydwu grach. Pierwotnie bazową techniką miała być całościowa analiza gameplayu, jednakże sama analiza zawartości okazała się bardziej przydatna dla zidentyfikowania miejsc, w których w obydwu badanych tytułach pojawiają się reprezentacje władzy oraz ich kontekstu fabularnego. Oczywiście została ona uzupełniona analizą gameplayu, jednak rola tej drugiej miała charakter pomocniczy. Badane były jedynie podstawowe wersje obydwu gier, nieuwzględniające dodatków typu dlc. Materiał filmowy z obydwu tytułów został wprowadzony do programu wspomagającego analizę treści, a następnie poddany ręcznemu kodowaniu przy użyciu reguł interpretatywnej analizy fenomenologicznej ${ }^{6}$, by wyodrębnić interesujące z perspektywy badania treści. Całkowity czas przeanalizowanego materiału to około trzydziestu Godzin (19 z Wiedźmina, 11 z Inkwizycji). Należy też zauważyć, że pewnym ograniczeniem badania jest to, że obydwa tytuły były analizowane w swojej angielskiej wersji, co może powodować niewyłapanie różnic, które mogły pojawić się zarówno w polskich wersjach obu gier, jak i między polskimi i angielskimi wersjami. O obecności tego typu różnic ostrzegał m.in. Tomasz Z. Majkowski, gdy w swoim wystąpieniu? zaznaczał, że angielskie tłumaczenie trzeciego Wiedźmina nie oddaje roli, jaką w grze odgrywa, identyfikowana jako polska, kultura picia. Dlatego też w ostatecznej wersji badania analizie zostaną poddane również polskie wersje obydwu gier. Dodatkowo pozwoli to zapobiec problemom przy późniejszej części badania, w której będą przeprowadzane wywiady oraz analiza z przejść gry osób, które grały zarówno w wersję polską, jak i angielską. Jednakże domniemywać należy, że

5 B. Schweiger Relacje władzy w polu wytwórstwa gier komputerowych „"Czas kultury” $2015 \mathrm{nr} 2$.

6 K. Jørgensen Gameworld Interfaces, The MIT Press, London 2013; K. Jørgensen Players as Coresearchers: Expert Player Perspectives as an Aid to Understanding Games, "Simulation \& Gaming" 2012 No. 43 (3).

7 T.Z. Majkowski Temerian Rye: on uses and abuses of alcohol in The Witcher3, CEEGS 2015, Kraków 2015. 
zasadnicza struktura fabularna obydwu tytułów pozostaje niezmieniona, a co za tym idzie, także komunikowane przez nią treści. Analiza gameplayu polegała na przejściu części questów powiązanych z częściami fabuły, w których zidentyfikowano reprezentacje władzy przy równoczesnym ich nagrywaniu wraz z komentarzem badacza. Uzyskany w ten sposób materiał został również wprowadzony do programu wspomagającego analizę treści i zakodowany. Należy też dodać, że badacz wcześniej przeszedł obydwie z omawianych produkcji. Użycie komputerowego wspomagania w socjologicznych badaniach z dziedziny analizy treści oraz analizy zawartości jest obecnie standardem. Metody te pierwotnie stworzone jako sposób analizy prasy ${ }^{8}$ zostały z powodzeniem wykorzystywane w badaniach np. literatury naukowej czy filmu? . Wielu badaczy wskazuje na liczne zalety zastosowania tego typu narzędzi, takie jak polepszenie trafności oraz rzetelności przeprowadzanych nimi badań, zwiększenie intersubiektywnej komunikowalności wyników czy dogłębności analizy ${ }^{10}$. Skupienie się na analizie cutscen powoduje, że to właśnie warstwa fabularna została ddokładniej zanalizowana, jednakże, jak można przeczytać w późniejszej części tego artykułu, interakcja, w jaką wchodzi fabuła z zasadami i rozgrywką, jest elementem kluczowym dla wymowy obydwu tytułów.

Na podstawie uzyskanych w badaniu kodów wyodrębniono 13 wymiarów, różniących sposoby przedstawiania władzy politycznej w Dragon Age: Inquisition i w Wiedźminie III. Następnie wskazano, w jaki sposób na ich interpretację oddziałuje powstały w zetknięciu z niektórymi typowymi dla gier RPG mechanikami dysonans ludonarracyjny.

Pierwszym wymiarem jest pozycja postaci, którą kieruje gracz względem instytucji politycznych. Badane gry stoją tu w opozycji do siebie, gdyż w Wiedźminie III postać gracza nie jest częścią żadnej organizacji politycznej, natomiast w Dragon Age bardzo szybko dołącza do ścisłego kierownictwa inkwizycji, by mniej więcej w połowie gry stanąć na jej czele. Ta różnica w usytuowaniu postaci stanowi bardzo ważną ramę dla interpretacji przedstawień politycznej władzy w badanych grach, ponieważ obydwie starają się czynić rozróżnienie między moralnie dobrym bohaterem, a resztą świata, tyle że

8 K. Krippendorff, Content Analysis: An Introduction to Its Methodology, 2013. ory and method of social representations, "Asian Journal of Social Psychology” 1999 No. 2 (1), s. $95-125$. 
Dragon Age rozszerza równocześnie moralną rację bohatera na organizację, którą ten kieruje. Jak zostanie pokazane przez porównanie następnych wymiarów, ma to kluczowe znaczenie dla sposobu, w jaki są przedstawiane polityczne instytucje w obydwu tytułach, gdyż stawia inkwizycję w innym porządku moralnym niż resztę organizacji politycznych obecnych w Dragon Age. Inkwizycja ratuje świat, gdy inne polityczne instytucje starają się po prostu dbać o swoje interesy. W Wiedźminie natomiast wszystkie instytucje polityczne działają w tym samym porządku i są zainteresowane jedynie realizacją partykularnych celów. Obie gry negatywnie odnoszą się do polityczności, jednak czynią to w inny sposób. Dragon Age przeciwstawia sobie władzę ponadpolityczną i władzę polityczną, a Wiedźmin przeciwstawia prywatne politycznemu.

Drugim elementem, na który warto zwrócić uwagę, gdy analizujemy usytuowanie bohaterów graczy obydwu gier względem reprezentacji politycznej władzy, jest to, w jakiej pozycji znajdują się oni do narracji o ratowaniu świata. Jest ona obecna w obydwu tytułach w Dragon Age Inkwizycja stara się zamknąć wyrwy powstałe między zamieszkiwanym przez demony światem duchowym a materialnym, tym samym krzyżując plany Koryfeusza, maga pragnącego stać się nowym bogiem. W Wiedźminie Avallac'h i Ciri starają się zatrzymać białe zimno, wielką międzywymiarową katastrofę mającą pochłonąć świat, w którym rozgrywa się gra. Postać gracza jednak znajduje się tu, w przeciwieństwie do Dragon Age, na uboczu tej narracji, zostaje wplątana w związane z nią wydarzenia, ponieważ stara się odnaleźć Ciri i jej pomóc. Równocześnie to nie kierowany przez gracza Geralt ratuje świat przed wielką katastrową, a właśnie jego przybrana córka. Rolę gracza w tym wątku najlepiej opisuje zdanie wypowiedziane przez Ciri do Geralta, gdy ta, mimo jego protestów, przechodzi przez elficki portal, by skonfrontować się z białym zimnem „What can you know about saving the world, silly? You're but a witcher" (Co możesz wiedzieć o ratowaniu świata, głuptasie? Jesteś tylko wiedźminem.) Geralt nie jest więc bohaterem ratującym świat, pełni rolę pomocnika, a postawa Ciri przekonanej o potrzebie poświęcenia się, by zapobiec wielkiej katastrofie, przysparza mu cierpienia, gdyż podkreśla jego bezsilność w tej sytuacji. W Dragon Age natomiast Inkwizytor jest wybrańcem, postacią konieczną do pokonania Koryfeusza. Bez znajdującego się na jego ręce znamienia pozwalającego na zamykanie wyrw, misja inkwizycji jest niewykonalna. Dwie równoległe ścieżki fabularne wspierają interpretację Inkwizytora bądź to jako namaszczonego przez Andraste boskiego wybrańca, bądź jako „porządnego człowieka", który ze względu na sytuację, w której się znalazł, jest zmuszony 
stanąć na wysokości zadania i powstrzymać zagrożenie. Równocześnie narracja ustami doradców Inkwizytora ciągle podkreśla sprawstwo inkwizytora w procesie ratowania świata.

Trzecim wymiarem jest przedstawienie motywacji głównych antagonistów. W Dragon Age Koryfeusz jest przedstawiony jako niebezpieczny szaleniec, starający się podważyć metafizyczne status quo. Jest zagrożeniem dla świata, a jego próby osiągnięcia boskiego statusu są jednoznacznie określane jako złe, i to złe właśnie dlatego, że podważają owo status quo. W żadnym momencie gra nie przedstawia jego wizji rewolucyjnej przemiany świata jako dającej się uzasadnić. Natomiast pojawiający się w Wiedźminie III Eredin działa w porządku politycznym. Jego motywacją jest chęć uratowania rodaków z niszczejącego świata, w którym żyją. Dodatkowo działa on w taki sam sposób, w jaki działają inni przywódcy politycznych instytucji pojawiający się w Wiedźminie, tj. stara się za wszelką cenę osiągnąć swoje cele. Nie myśli tylko o uratowaniu Aen Elle, ale też o tym, jak zapewnić im dominację w nowym świecie. Dziki Gon Eredina, gdy odrzemy go na chwilę z jego nadnaturalnej otoczki, nie różni się w sposobie funkcjonowania od Armii Nilfgardu czy Krain Radowida, gdyż realizuje polityczne cele za pomocą środków militarnych. Zło Eredina nie różni się niczym od zła innych przywódców politycznych świata Wiedźmina. Powstaje, gdy polityczne interesy zaczynają wkraczać w sferę prywatną. Zarówno Eredin, jak i jego Dziki Gon są źli, ponieważ chcą poświęcić Ciri dla realizowania swoich politycznych interesów, tym samym rozdzielając ją i jej przybraną rodzinę. Geralt i jego przyjaciele przeciwstawiają się więc niszczeniu ich prywatnego życia przez działania polityczne i stanowią rodzaj fantazji, w której prywatność ma tyle siły, by skutecznie pokrzyżować plany polityce. Tak więc to nie motywacje Eredina są przedstawione jako problematyczne, a fakt, że działa on politycznie.

Czwarty element, który okazał się istotny w analizie, dotyczy już bezpośrednio sposobu przedstawiania instytucji, a nie stosunku, jaki mają do nich poszczególne postaci. Istnieje bowiem różnica w tym, w jaki sposób obie gry konceptualizują związek między organizacją polityczną i legitymizacją jej władzy. W Wiedźminie, jeżeli dana instytucja ma wystarczająco mocny oręż czy sprawną dyplomację, na pewno będzie potrafiła wykorzystać je jako środek do legitymizacji swoich działań. Władza legitymizuje się więc sama. Nie potrzebuje zewnętrznego źródła, które uprawomocnia ją do działania. Narracja Wiedźmina podkreśla więc brak znaczenia legitymizacji dla funkcjonowania władzy. W Dragon Age natomiast sytuacja przedstawia się zupełnie inaczej. Legitymizacja jest kwestią kluczową dla całej fabuły. Gra poświęca bardzo 
dużą część narracji na pokazanie, że tym właśnie, co różni Inkwizytora od Koryfeusza, jest to, że ten pierwszy został religijnie namaszczony jako panujący przez Justynię V. Dragon Age stara się ramować konflikt jako rozgrywający się między uprawomocnioną władzą a uzurpatorem. Siły Koryfeusza mogą być większe, jego magia potężna, ale inkwizycja wygrywa, ponieważ jej panowanie jest legitymizowane. W tym sensie w świecie Wiedźmina prawdziwe jest powiedzenie, że „siła stanowi o słuszności”, natomiast w Thedas słuszność stanowi o sile.

Piątą interesującą kwestią są skutki działania organizacji politycznych. W Wiedźminie III funkcjonowanie każdej instytucji politycznej jest dla kogoś krzywdzące. Tak jest z militarnymi podbojami Nilfgardu, gdy w ich kontekście padają stwierdzenia, że nieważne jest, jak cywilizowanie mają się obchodzić z podbitymi społecznościami, „żołnierze zawsze będą żołnierzami”. Podobnie jest z doprowadzającym do licznych pogromów religijnym odrodzeniem Świątyni Wiecznego Ognia. Nawet stosunkowo najbardziej pozytywnie przedstawione Skellige ma prawa niesprawiedliwie skazujące na infamię Skjalla w zasadzie za to, że starał się pomóc Ciri. W Dragon Age sprawy przedstawiają się trochę inaczej. Co prawda konflikt między magami a templariuszami jest ukazywany jako niszczycielski dla krain, w których się rozgrywa, ale dość szybko dowiadujemy się, że bardziej radykalne elementy w obydwu walczących frakcjach są podsycane przez zakulisowe działanie Koryfeusza. Równocześnie narracja skupia się dużo bardziej na tym, że obie strony dysponują znaczącymi argumentami za swoimi działaniami i że sytuacja zmusza je do funkcjonowania w określony sposób. Jeżeli spotykamy ofiary działania czy to rewolucji magów, czy zakonu templariuszy, są one ramowane? jako ofiary złych skorumpowanych części tych instytucji, a więc, coś, czemu można zapobiec, jeśli dana instytucja działa prawidłowo. W Wiedźminie III ofiary są skutkiem prawidłowego działania instytucji. Co nawet ważniejsze, w Dragon Age istnieje Inkwizycja: organizacja bez skazy, której żołnierze nie wyżywają się na cywilach i zawsze stają w ich obronie, która nigdy nie popełnia błędów w określeniu tego, kto jest jej przyjacielem, a kto wrogiem, której działania zawsze prowadzą do polepszenia sytuacji i nie wiążą się z niepożądanymi kosztami.

W tym miejscu warto poruszyć również szerszy kontekst funkcjonowania instytucji politycznych. Jak stwierdzono w poprzednim akapicie, w grze CP Projekt Red funkcjonowanie każdej organizacji wiąże się nierozłącznie z licznymi systemowymi problemami. Niejednokrotnie problemy te są immanentną częścią modus operandi przedstawionych organizacji. Widzimy to np. w scenie, w której Geralt jest świadkiem rozmowy między dwoma szabrownikami, 
wynoszącymi sprzęty z dawnego domu Triss Merrigold, a dowódcą Novigradzkich łowców czarownic, Kalebem Menge. Poucza on szabrowników, że co prawda czarodzieje zostali wyjęci spod prawa, ale rabowanie ich dobytku nadal jest przestępstwem, ponieważ to świątynia wiecznego ognia jest instytucją upoważnioną do „rekwirowania” majątku heretyków. Rabowanie ich dobytku godzi zatem w jej interesy. Świątynia wiecznego ognia jest tutaj przedstawiona jako interesowna i szukająca zysku kosztem ludzi, których prześladuje. Co ciekawe Inkwizycja w Dragon Age też rekwiruje majątek swoich przeciwników, jednak fabuła nie uznaje tego za problematyczne. Bardzo symptomatyczna jest tutaj scena, w której Inkwizytor i Józefina rozmawiają z Markizem Du Rellion. Domaga się on zwrotu wioski Haven, ówczesnej bazy operacji Inkwizycji. Argumentuje, że przekazał tę ziemię w użytkowanie Zakonowi Andrastiańskiemu i Justynii V, nie Inkwizycji, będącej osobną instytucją, w tamtym czasie uznaną przez większość zakonu za heretycką. Jednak w tym wypadku to próby odzyskania swojej własności podejmowane przez Markiza są przedstawione jako interesowne i szkodliwe. Nie jest on gotowy poświęcić swojej ziemi dla większego dobra, dlatego jego zachowanie zostaje napiętnowane jako coś negatywnego. Możemy więc wyraźnie dostrzec inne wartościowanie dochodzenia swoich racji w sferze publicznej i prywatnej w obydwu grach. W Wiedźminie III to instytucje są tym, co niesprawiedliwie prześladuje i zabiera majątek słabszym. W Dragon Age to prywatne jednostki narażają na szwank dobro ogółu, kwestionując zasadność rekwirowania ich dóbr przez instytucje.

Następnym tematem, na który należy zwrócić uwagę, jest to, w jaki sposób oba tytuły widzą konflikt w kontekście polityki. W grze CD Projekt Red polityka ma zawsze, żeby użyć kategorii Chantal Mouffe" miejscem, w którym rządzone tą samą logiką instytucje walczą, by realizować swoje polityczne cele. Nie możemy więc na tym poziomie mówić o konflikcie dobra ze złem, a jedynie o konflikcie interesów. W grze BioWare natomiast agonistyczna konfrontacja jest tym, co ukrywa konflikt antagonistyczny. Walka między magami i templariuszami jest tym, co pozwala rozwinąć się złu w postaci Koryfeusza. Zażegnanie tego politycznego konfliktu staje się koniecznością, by pokonać większe zło. Obie gry są więc do pewnego stopnia krytyczne w stosunku do konfliktu politycznego, jednakże gdy w Wiedźminie wszystkie instytucje polityczne są równe względem tej krytyki, to w Dragon

11 Ch. Mouffe On the Political, Routledge, New York 2005; tejże Ch. Mouffe Agonistics: Thinking The World Politically, Verso, London 2013. 
Age Inkwizycja ma specjalny status, ponieważ mimo że funkcjonalnie jest organizacją polityczną, to dzięki posiadaniu legitymizacji przestaje funkcjonować w agonistycznym porządku konfliktu politycznego, a zaczyna w antagonistycznym walki dobra ze złem. Ten specjalny status daje jej możliwość bycia arbitrem i sprawiedliwego rozwiązywania sporów politycznych.W tym sensie, by znów odwołać się do Mouffe, Wiedźmin reprezentuje logikę polityczną, natomiast gra BioWare postpolityczną. Oczywiście postpolityczność ta jest przeniesiona w ramy settingu fantasy, gdzie technokratyczne myślenie zostaje zastąpione kategoriami walki dobra ze złem.

Z problemem legitymizacji władzy i funkcjonowania organizacji politycznych w obydwu grach bezpośrednio wiąże się status instytucji religijnych. Jak zauważono wcześniej, w grze BioWare Instytucje religijne odgrywają szczególną rolę jako źródło, z którego wypływa legitymizacja. Mimo że działają w sferze politycznej, mają uprzywilejowany status względem innych instytucji. Sama Inkwizycja jest organizacją religijną, a jej status jest bardzo interesującym zagadnieniem. W scenie, w której zostaje ona publicznie proklamowana, widzimy Cullena przybijającego do drzwi świątyni zakonu w Haven artykuły obwieszczające powstanie Inkwizycji. Gest ten w dość jasny sposób nawiązuje do przybicia tez przez Marcina Lutra do drzwi katedry w Wittenberdze. Podobnie dość szybko zostaje ona uznana za ruch heretycki przez większość kapłanów zakonu Andrasty. Odwołania do reformacji i duchowego odnowienia są więc tutaj dość jasne. Równocześnie jednak już w następnej scenie dowiadujemy się, że Inkwizycja powstała z polecenia niedawno zmarłej Boskiej (Andrastiańskiej odpowiedniczki papieża) i maa jej błogosławieństwo. Równocześnie sama zakonna większość reprezentowana w grze głównie przez postać kanclerza Roderyka również nie jest tak naprawdę skorumpowana czy zła, a jej błędem jest zbyt biurokratyczne spojrzenie na świat. Zresztą i to niedociagnięcie zostaje zrehabilitowane, gdy reprezentujący zakon Roderyk poświęca się, by uratować ewakuujących się podczas ataku Koryfeusza mieszkańców Haven. Z jednej strony narracja Dragon Age stara się przedstawiać Inkwizycję jako nowy ruch niosący duchowe odrodzenie, z drugiej jednak dba o to, aby zasadność jej legitymizacji nie mogła zostać podważona. W Grze CD Project Red natomiast instytucje religijne nie mają specjalnego statusu i funkcjonują jak wszystkie inne organizacje. Dobrym przykładem jest wątek, w którym Geralt pomaga trupie bardów, nękanych przez grupę opryszków wynajętą przez kapłanów wiecznego ognia.Źródłem owego prześladowania jest to, że trupa pozwoliła sobie wcześniej na napisanie utworu niepochlebnie wyrażającego się o działaniach świątyni. Instytucje 
religijne są uznawane w Wiedźminie III za rodzaj instytucji politycznej i poddane takiej samej krytyce.

Prowadzi to do postawienia pytania, w jaki sposób obie gry konceptualizują dobro i zło w kontekście polityki. W przypadku Dragon Age, jak wynika z poprzedniego akapitu, konflikt między esencjalnie rozumianym dobrem a złem stanowi oś fabuły i są w niego zaangażowani nie tylko bohaterowie, ale też organizacje, do których należą. Ma on więc wymiar nie tylko personalny, ale i instytucjonalny. W grze CD Projekt Red podział na dobro i zło zachodzi na linii prywatne - polityczne. Jak wskazano wcześniej, działanie instytucji politycznych zawsze powoduje powstanie zła, które odbija się na życiu bohaterów. Sfera prywatna natomiast jest miejscem, w którym dobro jest możliwe. Widzimy to np.w zakończeniach, z których najbardziej pozytywnym jest to, w którym Ciri wraca, by zostać wiedźminką, a Geralt osiada w małej chatce na uboczu z jedną ze swoich wybranek, by od czasu do czasu wspólnie ze swoją przybraną córką zapolować na potwory. W drugim neutralnym zakończeniu Ciri zostaje cesarzową Nilfgardu, przez co zostaje rozdzielona z Geraltem. Co ciekawe, nawet w tym wariancie, co czyni z niej dobrą władczynię, jest odziedziczona po Geralcie „Basic human decency” (Podstawowa ludzka przyzwoitość). W negatywnym zakończeniu co prawda Dziki Gon zostaje pokonany, a świat uratowany od Białego Zimna, ale los Ciri jest niepewny, a zdruzgotany rozłąką Geralt pozostaje samotny. Podobnie gdy pomaga on magom, czyni to z osobistych pobudek, a w samym przedstawieniu postaci magów dominują elementy związane z ich prywatnym życiem, a nie usytuowaniem społecznym czy politycznym. W wyniku takiego ramowania dobra i zła w Wiedźminie III nieobecna jest kategoria większego dobra, a przynajmniej nie jest ona rozumiana w kategoriach politycznych. W Dragon Age natomiast stawianie osobistych relacji ponad większym dobrem jest stygmatyzowane. Najlepiej widać to w wątku Magistra Gereona Alexiusa. Jego usilne starania, by uratować swojego nieuleczalnie chorego syna Felixa, są przedstawione jako szkodliwy i próżny wysiłek. To właśnie ze względu na przywiązanie do swojego syna Alexius decyduje się współpracować z Koryfeuszem, a brak umiejętności pogodzenia się z nadchodzącą śmiercią syna doprowadza Gereona do zguby. W innym, pobocznym wątku niechęć Leliany do poświęcenia swoich podwładnych doprowadza do niewykrycia w porę Koryfeuszowego spisku. Wątek ten jest dla Leliany nauczką, dzięki której może lepiej służyć Inkwizycji.

Pora poruszyć kolejną fasetę przedstawień politycznych konfliktów obecnych w obu grach. Mianowicie, komu przyznawana jest racja. W grze BioWare 
sytuacja pozostaje spójna, racja leży po stronie Inkwizycji, ponieważ ma ona uprzywilejowaną pozycję dzięki swojej legitymizacji. Wśród instytucji nieposiadających uprzywilejowanego statusu rację mają te, które wskaże gracz rękami Inkwizycji. W Wiedźminie racja nierozerwalnie wiąże się z rolą ofiary. $\mathrm{W}$ tej grze tylko ofiarom zostaje przyznany przywilej niemylenia się. Jednak obowiązuje on jedynie do czasu, w którym dana postać w roli ofiary pozostaje. Narracja abstrahuje więc od okropieństw dokonywanych przez magów, eksperymentów na ludziach i politycznych machinacji w momencie, w którym stają się oni ofiarami pogromów. Są oni opisywani wtedy w czysto personalnym kontekście, zostają wyciągnięci z kontekstu grupowego. Przestają być członkami większej całości, stają się jednostkami, dlatego też stają się tacy, że warto ich uratować. Znów gra czyni tutaj rozróżnienie między większymi społecznymi całościami, które muszą ze swojej natury powodować zło, oraz jednostkami, które mogą być dobre. Jednostki więc, dopóki działają w instytucjonalnym politycznym kontekście, dopóty zmuszone są czynić zło. Dopiero oderwanie od tego kontekstu pozwala im nie być złymi. Niemniej jednak pozostają one ciągle członkami swojej grupy. To, co zostaje oderwane, to kontekst niegodziwości, jaką funkcjonowanie tej grupy powoduje. W Wiedźminie więc bardzo ważna jest figura spersonalizowanej ofiary, gdyż paradoksalnie pozwala na czasowe przyznanie moralnej racji większym kategoriom społecznym.

Jeżeli o kategoriach społecznych mowa, owocne okazuje się przyjrzenie temu, jak w obydwu grach funkcjonuje kategoria „zwykłych ludzi”. Mam tu namyśli to, w jakiej relacji do polityki znajdują się postaci nieposiadające specjalnych mocy czy nieprowadzące awanturniczego trybu życia: rolnicy i mieszczanie, cywile Dragon Age i Wiedźmina III. W grze CD Projekt Red już samo wkroczenie w dziedzinę politycznego działania doprowadza do powstania zła. Jeżeli więc zwykli ludzie zaczynają organizować się i działać politycznie, zrównują swój status z innymi bytami politycznymi. Najlepiej widać to $\mathrm{w}$ wątku, w którym wiedźmin pomaga Keirze Metz zdobyć notatki dotyczące badań nad gorączką krwotoczną Carioną. Poznaje wtedy historię wieży na jeziorze w Velen. Podczas wojny z Nilfgardem schroniła się w niej rodzina miejscowego lorda. Powodowana głodem i dawnymi zaszłościami miejscowa społeczność postanowiła wedrzeć się do wieży i wymierzyć, w jej mniemaniu, sprawiedliwość swoim dawnym panom. Konfrontacja kończy się oczywiście krwawo, przez co na opuszczoną wieżę spada klątwa. Spontaniczne organizowanie się zwykłych ludzi w Wiedźminie zawsze odbywa się w kontekście takim jak pogrom czy zamieszki i najczęściej ma niszczycielski 
charakter. W grze BioWare natomiast omawiana kategoria społeczna pozostaje bierna, dopóki nie zaczyna działać w obrębie ustalonych wcześniej ram instytucjonalnych. W Dragon Age funkcjonowanie w ramach instytucji jest warunkiem koniecznym działania politycznego. Nawet najbardziej oddolna i zdecentralizowana organizacja, zrzeszająca "zwykłych ludzi” chcących odegrać się na możnych świata Thedas, Friends of Red Jenny (Przyjaciele Rudej Jenny) ciągle pozostaje organizacją. Ma swoje struktury, sposób działania, nazwę i ramy instytucjonalne. W Dragon Age nie stygmatyzuje też w ten sam sposób, jak Wiedźminie III, działania zwykłych ludzi. Przyjaciele Rudej Jenny nie zawsze są niszczycielskim żywiołem, jak w przypadku innych instytucji, wplątani są w rywalizację o agonistycznym charakterze i poddają się arbitrażowi Inkwizytora.

Powyższy akapit dobrze łączy się z tym, jak obie gry przedstawiają procesy społeczne. Jak widzimy w Wiedźminie III, spontaniczne działanie społeczne jest przedstawiane jako rodzaj niebezpiecznego, niszczycielskiego żywiołu. I podobnie jak naturalna katastrofa nie daje się zatrzymać. Gdy Geralt wraca do Novigradu po wyprowadzeniu z niego magów, napotyka przy wejściowej bramie stosy ze spalonymi nieludźmi. Rozpoczyna wtedy monolog o tym, że nienawiść i uprzedzenia nigdy nie zostaną wyrugowane. Ludzie zawsze będą potrzebowali kozła ofiarnego i dlatego zawsze będą kierować swój gniew przeciw inności. Monolog ten ma bardzo esencjalistyczny i fatalistyczny wydźwięk. Zakłada, że ze względu na ludzką naturę zbiorowe działania zawsze prowadzą do tragedii, a procesy społeczne są przedstawianie jak coś, co przynosi ofiary, coś przed czym da się uratować część zagrożonych tym żywiołem, ale na pewno nie wszystkich. Nie ma się więc wpływu na procesy społeczne, ponieważ są one wynikiem ludzkiej natury, która w swojej zbiorowej, politycznej części jest zła. W Dragon Age procesy społeczne są przedstawione w mniej pesymistyczny sposób. Inkwizycja ma możliwość wprowadzania trwałych zmian w funkcjonowaniu społeczeństw Thedas. Jest np. w stanie zapewnić magom większe swobody bądź też możliwość samostanowienia. Tak samo może wpłynąć na polepszenie jakości życia i zwiększenie politycznych praw Elfów w Cesarstwie Orlais. Procesy społeczne, nawet jeśli brutalne, jak np. powstanie magów, są przedstawiane jako uzasadnione i mogące mieć pozytywne skutki. Oczywiście warunkiem jest tutaj rezygnacja z otwartego konfliktu, przystąpienie do negocjacji, gotowość na ustępstwa i poddanie się przewodnictwu Inkwizycji. Równocześnie rewolucyjna bezkompromisowa zmiana kosmologicznego status quo, którą stara się wprowadzić Koryfeusz, jest przedstawiana jako coś równoznacznie złego. 
Ostatni z wymiarów będzie się skupiać na samym graczu i jego relacji do narracji, co pozwoli na płynne przejście z analizy warstwy fabularnej do rozważań na temat towarzyszących jej mechanik. Narracja Wiedźmina ciągle podkreśla brak wpływuGeralta, a przez to i kierującego nim gracza, na świat wielkiej polityki i procesów społecznych. W zasadzie cała fabuła opiera się na wykonywaniu przez Geralta niechcianych zadań, po których zleceniodawca, będący zazwyczaj przedstawicielem jakiejś politycznej instytucji, obiecuje przekazać informacje pomocne w znalezieniu najpierw Yennefer, a później Ciri. Gracz sterujący Geraltem nie ma możliwości ominięcia tego procesu, by np. przez zastraszenie czy oszukanie przyspieszyć poszukiwania Ciri. Musi razem z nim wykonywać zlecone zadania. Staje się więc niejako narzędziem realizującym wewnątrzgrowe interesy postaci niezależnych. Przez co zostaje zaznaczone poczucie braku sprawstwa w warstwie społecznej i politycznej. W grze BioWare również pojawia się ten brak poczucia sprawstwa, jednakże gra stara się go skrzętnie ukryć. Na każdym kroku doradcy Inkwizytora informują gracza, że los świata, Inkwizycji czy też napotkanych przez niego osób zależy tylko od podejmowanych przez niego decyzji. Jednakże gdy przyjrzymy się bliżej relacji Inkwizytora i jego rady, okazuje się, że tak samo jak Geralt, jest on narzędziem służącym do realizacji interesów swoich doradców. To nie on dostarcza strategii działania Inkwizycji, jest natomiast zmuszony wybierać między zaprezentowanymi z góry zestawami możliwości, którym nie jest w stanie się przeciwstawić.

Opisana w powyższym akapicie sytuacja wynika z interakcji warstw fabularnej i mechanicznej obydwu tytułów. Dokładniej z mechaniką questów. Quest jest typową dla gier RPG konstrukcją: postać gracza otrzymuje zadanie, jego wykonanie wiąże się z uzyskaniem nagrody, która w przypadku questów o kluczowym znaczeniu dla gry oznacza też posunięcie narracji do przodu. Zarówno w Wiedźminie III jak i w Dragon Age gracz nie jest wstanie ominąć istotnych dla gry questów, ponieważ są one warunkiem przedstawienia dalszej fabuły gry i otwarcia przed nim kolejnego etapu rozgrywki. Questy ze względu na swoją strukturę są reaktywne. Postać gracza musi poruszać się w zdefiniowanych wcześniej ramach sytuacyjnych i mechanicznych, poza które nie pozwala mu wyjść gra. O ile w Wiedźminie natura questów wspiera zaprezentowaną narrację, reaktywność i zależność od wcześniej zdefiniowanych ram podkreśla bezsilność Geralta w z regułami funkcjonowania „wielkiego świata", o tyle w Dragon Age mechanika ta podważa narrację. Jak wspomniano wcześniej, Inkwizytor jest w stanie jedynie wypełniać powierzone mu przez doradców zadania. Sytuacja ta wynika ściśle z ograniczeń 
narzucanych przez mechanikę. Widzimy więc, jak w przypadku gry BioWare dochodzi do ludonarracyjnego dysonansu ${ }^{12}$, czyli retorycznego rozejścia się komunikatu przekazywanego przez fabułę i mechanikę czy też nieścisłości między nimi.

Nie jest to jedyny wart poruszenia przykład tego zjawiska. Następnym jest wpływ zjawiska grindu. Grind (dosłownie z angielskiego szlifowanie) to zachowanie graczy wypływające z mechaniki rozwoju postaci. Żeby być w stanie pokonać potężnego przeciwnika, postać gracza musi najpierw stać się wystarczająco silna. Aby to zrobić, musi poświęcić dużo czasu na różnego rodzaju poboczne zadania. Problem polega jednak na tym, że zarówno w gra CD Projekt Red, jak i BioWare opowiadają historię o bohaterach już doświadczonych i posiadających całkiem spore umiejętności, którzy nie marnowaliby czasu na zbieranie dwustu kozich futer, by uszczęśliwić zubożałego trapera, ponieważ mają zwyczajnie ważniejsze rzeczy na głowie. Sednem problemu jest to, że mechanika rozwoju postaci, podobnie jak mechanika questu, współgra bardzo z fabułą o strukturze bajki magicznej, co niestety powoduje, że gdy używamy ich wraz z innymi typami fabuł, dochodzi do dysonansu. Narracja mówi w jednej konwencji, a mechanika w drugiej. Rozdźwięk ten jest zdecydowanie bardziej odczuwalny w Wiedźminie III i znacząco wpływa na odbiór fabuły, ponieważ o ile w Dragon Age dużą część zadań pobocznych da się wytłumaczyć koniecznością zwiększania wpływów Inkwizycji, o tyle w Wiedźminie brak takiego uzasadnienia. Przez co, grając w Wiedźmina, tracimy poczucie konieczności poszukiwania Ciri. Co ciekawe, gdy jedynie oglądamy jedna po drugiej cutsceny, poczucie to zostaje zachowane.

$\mathrm{Z}$ rozwojem postaci bardzo blisko związana jest mechanika lootowania (ograbiania). Gracz ma możliwość ograbienia ciała pokonanego właśnie wroga czy potwora w celu zdobycia przydatnych w dalszej grze przedmiotów. To właśnie w zetknięciu z tą mechaniką rozdźwięk między narracyjnymi postawami w stosunku do instytucji politycznych a tymi zawartymi w mechanice staje się najgłośniejszy. W opisywanej powyżej scenie rozmowy między Kalebem Menge a szabrownikami narracja przedstawia Geralta jako kogoś moralnie lepszego niż reszta postaci obecnych w scenie. Jednak trudno myśleć o nim w ten sposób, gdy zaledwie godzinę wcześniej jego rękami zabiło się grupę siedzących przy ognisku trzech mężczyzn, a następnie obrabowało ich z dobytku tylko dlatego, że nad ich głowami widniał czerwony

12 C. Hocking Ludonarrative dissonance in bioshock: the problem of what the game is about, w: Well Played 1.0: Video Games, Value and Meaning. ETC Press, Pittsburgh 2009. 
napis „brigands” (rozbójnicy). W działaniach dopuszczalnych przez mechanikę Geralt okazuje się więc wcale nie lepszy od krytykowanej przez siebie władzy. W Dragon Age Inkwizytor i jego towarzysze również po każdym starciu ze swoimi przeciwnikami ograbiają ich ze wszystkich kosztowności, jednak fabuła w żaden sposób tego nie problematyzuje. Inkwizycja ciągle przedstawiana jest jako moralnie czysta, gdyż działa dla większego dobra. Więc mimo że jej działania powinny powodować niepożądane koszta, nie czynią tego, ponieważ fabuła pozostaje na nie ślepa.

Podsumowując całą analizę, możemy powiedzieć, że obie gry w różny sposób konceptualizują naturę i sposób funkcjonowania władzy politycznej. W jednej jest ona zawsze jednoznacznie szkodliwa, w drugiej brak szkodliwości czy też dobroczynność władzy są bezpośrednio związane z jej legitymizacją. Sama legitymizacja natomiast $\mathrm{w}$ świecie Wiedźmina odgrywa rolę poboczną, natomiast w Dragon Age jej posiadanie przez bohatera gracza jest kluczowe dla całej fabuły. Każdy z tytułów inaczej wartościuje opozycję polityczne - prywatne. W grze CD Projekt Red dobro prywatnych relacji jest przeciwstawione niegodziwości płynącej z natury funkcjonowania instytucji politycznych. W grze BioWare natomiast stawianie swoich prywatnych relacji ponad dobrem ogółu jest piętnowane i prowadzi do tragedii. Wiedźmin III równocześnie bardzo krytycznie odnosi się do każdego działania w sferze politycznej oraz związanych z nią procesów społecznych. W Dragon Age funkcjonowanie w sferze politycznej nierozerwalnie wiąże się z operowaniem w granicach jakiejś instytucji. Nie ma w nim więc przedstawienia spontanicznego działania politycznego. Wiedźmin III prezentuje bardziej spójną wizję funkcjonowania władzy politycznej, natomiast Dragon Age częściej przeskakuje między różnymi modelami jej wyobrażonego funkcjonowania. Oba tytuły zmagają się również z wspierającym ich subwersywne odczytania dysonansem ludonarracyjnym.

Pytanie jednak, jakie mogą być źródła różnic zawartych w obydwu tekstach. Pewną odpowiedź może dawać wpracowany przeze mnie na podstawie teorii ekonomii dóbr kulturowych Bourdieu ${ }^{13}{ }^{14}$, teorii kreolizacji Hannerza ${ }^{15}{ }^{16}$,

13

P. Bourdieu Męska dominacja, przeł. L. Kopciewicz, Oficyna Naukowa, Warszawa 2004.

P. Bourdieu Dystynkcja: społeczna krytyka władzy sądzenia, przeł. P. Biłos, Scholar, Warszawa 2005.

U. Hannerz Transnational Connections: Culture, People, Places, Routledge, London 1996.

G. Kjell, U. Hannerz, C. Westin Nationalism and internationalism in the Post-Cold War era, Routledge, London 2000. 
rozmyślań na temat natury władzy Barthes'a ${ }^{17} \mathrm{i}$ koncepcji hegemonii kulturowej zaproponowanej przez Lee i Murphy ${ }^{18}$ model: media, jakimi są gry komputerowe, wytwarzane są przez różne podmioty instytucjonalne, związane z konkretnymi regionalnymi subpolami globalnego pola produkcji gier komputerowych (które samo w sobie jest tematycznym subpolem pola produkcji kulturowej). Zasięg odbioru tych mediów oraz sposoby ich interpretacji zależą zarówno od tego, z jakim subpolem produkcji gier komputerowych związani są ich autorzy, jak i od tego, z jakich kultur wywodzą się ich odbiorcy. Pozycja danego regionalnego subpola może mieć charakter mieszczący się na kontinuum między centralnością a peryferyjnością. Pola centralne mają charakter hegemoniczny w stosunku do pól bardziej peryferyjnych. Zależność ta dotyczy zarówno obszaru ekonomicznego (więcej studiów wytwarzających gry i większe środki na ich wytwarzanie w polach centralnych, drenaż mózgów z pól peryferyjnych, zapewnianie bezpieczeństwa finansowego regionalnym studiom przez międzynarodowe korporacje), jak i kulturowego, gdzie owa zależność przejawia się w dostarczaniu przez centra gotowych wzorców gatunkowych, zarówno w warstwie fabularnej, jak i zasad. Widoczna jest również w niesymetrycznej znajomości motywów i nawiązań kulturowych pochodzących z centralnych i peryferyjnych pól produkcji. Zależności te zmuszają podmioty instytucjonalne związane z subpolami peryferyjnymi do naśladowania narracji i zbiorów zasad wywodzących się z centrum. Równocześnie pojawia się wśród ich członków potrzeba wyrażenia własnego punktu widzenia oraz własnej regionalnej narracji, która, w zależności od stopnia peryferyjności danego subpola, może zostać niezauważona, subwersywnie zinterpretowana lub też zinterpretowana prawomocnie ${ }^{19}$.

Wydaje się więc, że różnice mogą wypływać z różnej pozycji w subpolu produkcji gier komputerowych zajmowanym przez wytwarzające je polskie i kanadyjskie studia. Według tego modelu obraz władzy prezentowany w Dragon Age byłby bliższy sposobowi, w jaki politykę konceptualizują mieszkańcy krajów centralnych. Natomiast w Wiedźminie widoczne byłyby sposoby rozumienia władzy charakterystyczne dla obszarów półperyferyjnych. Reprezentacja władzy byłaby więc związana z regionalną kulturą i odzwierciedlała jej specyfikę. Tak np. niechęć do władzy politycznej wyrażana w Wiedźminie

R. Barthes Leçon, Seuil, Paris 1978.

A. Lee, B. Murphy Cultural Hegemony in the United States, Sage, Thousand Oaks 2000.

19

B. Schweiger Relacje władzy... 
byłaby symptomatyczna dla niechęci, jaką wobec tej władzy wyraża polskie społeczeństwo. Tak samo waga legitymizacji dla prawidłowego funkcjonowania władzy byłaby znacząca dla myślenia o władzy anglosaskich społeczeństw zachodnich. Należy jednak być świadomym ograniczeń zaprezentowanego modelu, nieuwzględniającego np., na razie, transnarodowych relacji występujących w ramach studiów odpowiedzialnych za stworzenie obydwu gier i tego, na ile występuje i ważna jest w nich opozycja między pochodzącą z jakiejś kultury grupą zarządzającą a resztą pracowników mających różne kulturowe tła. Równie problematyczna może być też relacja między posiadającym lokalny charakter studiem a globalnym wydawcą. Obie te kwestie, jak i wiele innych o podobnym charakterze, wymagają jeszcze analizy i zaimplementowania w modelu.

Oczywiście na obecnym etapie połączenie wniosków z przeprowadzonej analizy z przedstawionym modelem ma charakter hipotezy badawczej i musi zostać jeszcze zweryfikowane. Po pierwsze, potrzebne do tego będą jeszcze wspominane na samym początku tekstu badania przeprowadzone wśród odbiorców i wytwórców obydwu tytułów, które pozwolą na zbadanie ich interpretacji, stwierdzenie czy występują w nich jakieś regularności oraz czy ich spostrzeżenia pokrywają się z przeprowadzoną do tej pory analizą. Gdyby takie regularności pojawiły się i dodatkowo wpisywały się w zaproponowany w badaniu model, mogłyby stać się przyczynkiem do przeprowadzenia bardziej ustrukturyzowanych ilościowych badań tytułów wydawanych przez studia związane z centrami i peryferiami pola produkcji gier komputerowych, które pozwoliłyby na statystyczne zweryfikowanie zaproponowanej w tekście hipotezy. 
Abstract

\section{Bartłomiej Schweiger}

JAGIELLONIAN UNIVERSITY (CRACOW)

Representations of Power in Computer Games: Comparing The Witcher 3 and Dragon Age: Inqusition

Schweiger presents the preliminary outcomes of his doctoral research project on representations of power in The Witcher 3 and Dragon Age: Inqusition. The main method used in the first stage of this project was a computer-assisted analysis of the content of intros, outros, cutscenes, as well as dialogue sequences in the two games; gameplay analysis was a secondary reserach method. Based on the codes gained from this study, Schweiger isolates 13 dimensions that distinguish the ways in which political power is represented in the two games He then discusses how their interpretation may be influenced by a dissonance between the plot and the rules in these games.

\section{Keywords}

The Witcher 3 [Wiedźmin 3], Dragon Age: Inquisiton, representation of power, content analysis 